\title{
ANATTEMPT FOR THE PROTECTION OF SEXUAL DIVERSITY IN BRAZILIAN LAW
}

Marcos Vinicius Torres Pereira

Professor at the Department of Civil Law of the Federal University of Rio de Janeiro, Brazil.

\begin{abstract}
This article intends to talk about a democratic initiative of the Brazilian Bar Association to promote human rights and sexual diversity in Brazil. Brazil is walking up the road to protect LGBTI citizens and to legally recognize same-sex couples. The country has guaranteed many rights to homosexual couples and their children, but the lack of a specific act to rule these matters is a problem in a country whose legal system is still very dependent to legal acts and positivism. This work tries to show the state of art of homosexual couples' rights in Brazil and how the proposal of a new statute to protect the rights of LGBTI people, in all aspects of their daily life could protect them and contribute for a democratic society.
\end{abstract}

Keywords: Prejudice - Sexual Diversity - Protection.

\section{INTRODUCTION}

Homosexuality has always existed, but only a few decades ago homosexuals started being considered as equal as other citizens in the majority of countries; and in the last years their relationships have been recognized as families in some countries. Brazil - as well as other Latin American countries - was not indifferent to this worldwide -or at least occidental - movement.

Many contradictions may blurr the vision of Brazil as a paradise for sexual liberation. The country is known as a place where sex has no barriers, celebrations are everywhere all the time. Nevertheless, this utopic and at a certain point of view derogatory stigma does not correspond to daily life. Discrimination against women and homosexuals are frequent, sometimes with different approaches, but with a same root: a model of a sexist heterocentrical society based on the figure of the heterosexual husband and father. 


\section{A LONG HISTORY OF CENTURIES OF DISCRIMINATION}

The story of discrimination and persecution of homosexuals, and more precisely, those who dared choosing a different sexual orientation from the heterosexual model, may be focused in a view of them either as sinners, or criminals, or sick people.

The oldest and strongest cause for prejudice is surely religion. In the Middle Ages in Europe, homosexuals were persecuted as unnatural, because their attraction towards someone from the same sex was considered a deviation from the moral model preached by the Church ${ }^{1}$. Homosexual relations would not match the dogma of sex for procreation, and therefore it would not contribute to ensure the continuity of the Church's power by enlarging the Christian population. Homosexuals were therefore considered sinners.

Historical records show that the Inquisition burned miles of homosexuals in Europe and in the Americas, during European Colonization. Inquisition was more severe in Portugal, Spain and their colonies in the $16^{\text {th }}$ and $17^{\text {th }}$ centuries, due to the Catholic ContraReform Movement on the Iberian peninsula. This way, the Portuguese heritage to Brazil did not include only the language, the religion and the cultural traditions, but also the society model, the sexism, and the prejudice and persecution against homosexuals.

The Catholic Church was powerful in Portugal and influenced its legal system. The Royal Ordinances considered sodomy a crime and its adepts could be prosecuted, condemned and killed, especially by Inquisition, which was very powerful during Brazilian Colonization.

From the Brazilian Empire on, our autochthonous laws did not criminalize man-to-man sexual intercourse itself, but some crimes were often used to persecute homosexuals, such as transvestism, obscene acts and vagabond behaviour.

The new Criminal Code from 1940 did not change this approach nor contribute to end prejudice against homosexuals. Following on the footsteps of European Theories from Criminology and Legal Medicine broadcasted from the end of the $19^{\text {th }}$ Century on - the "homosexual" was first used by the German-Hungarian journalist Karl Maria Kertbeny in 1868 -, our authorities and intellectuals contributed to homophobia, because they disseminated the belief that homosexuality was caused by hormonal or psychiatric disturbs. The great development of psychology in the first half of the $20^{\text {th }}$ century was not enough to avoid that some homosexuals were sent to clinics and submitted to medical treatment in an attempt to turn them into heterosexuals. Only in 1973, homosexuality was removed of the North-American list of psychiatric disorders, which

1 See FORNE, Byrne. Homophobia: a History. New York, Metropolitan Books, 2011. p. 111-175. 
was followed in Brazil only in the eighties. In a global scale, only in 1991 - by the end of the century -, it was officially removed from the list of diseases of the World Health Organisation.

Recently, some Christian Congregations, like the Contemporary Christian Church in big cities in Brazil, seem to be more tolerant towards homosexuality, what makes them popular for many members of the LGBTI community. They welcome gays and lesbians and sometimes celebrate religious weddings - which are not necessarily recognized and welcome their children resulting from surrogacy motherhood, jointadoption or stepchild-adoption. They thus encourage homosexuals to form a family, something that is criticized by some LGBTI activists, for it corresponds to a family based in a heterosexual model, but something that corresponds to what many activists are fighting for in many countries.

\section{LIVING IN PARADISE IN BRAZIL?}

\subsection{DIFFERENT JURIDICAL STATUS FOR SAME-SEX COUPLES}

If we focus on the status of homosexuals from the clash of human rights on, we can notice that from the 1960s on we can set out a phase of development of gay culture in many occidental big cities and of the beginning of the fight for gay rights, with the raid on the Stonewall Inn and the rebellion that followed it in New York in 1969, as an unforgettable landmark of the fight for gay rights. By this time, gay activist groups were starting to organize themselves in Europe and in North America, where we can single out the figure of Harvey Milk ${ }^{2}$. In Brazil and in other Latin American countries, these movements were not so open, because of military governments that did not support minorities' rights at all.

The 1980s were marked by the phantom of AIDS, which was widespread in the gay community, but also witnessed a phase of victory for gay movements: the decriminalisation of homosexual relations in some major countries - a fight already started many years before and the fact that Denmark was the first country to open its legislation to recognize homosexual unions in 1989, but excluding them from a religious ceremony and from adoption.

After some years of battle, other concrete victories on the human rights field were achieved from the 1990s on. Many local and national courts have judged favourably against discrimination and to ensure

2 See MARCUS, Eric. Making Gay History: the Half-Century Fight for Lesbian and Gay Equal Rights. New York, Harper Collins, 2002. 
some rights to homosexual couples. Some Scandinavian countries followed on the Danish footsteps. They had won an important battle: they could have their unions recognized, but they could not get married, as straight people could do. Besides, they did not have all the rights granted to heterosexual couples. France approved its PACS Act in 1999, and established a sui generis model of partnership contract which made no distinction among homosexual and heterosexual partners ${ }^{3}$.

In the $21^{\text {st }}$ century, other countries in Europe legalized homosexual relationships. The recognition also arrived in Latin America ${ }^{4}$, South Africa, Australia and New Zealand, where homosexual marriage was approved for the first time in the area of Asia and the Pacific. It is remarkable that The Netherlands were the first country to allow homosexual marriage and joint adoption by homosexual parents in $2001^{5}$. Argentina, Belgium, Iceland, Spain, Sweden and Uruguay also legalized homosexual marriage. Portugal reformed its Civil Code to introduce homosexual marriage.

In the Americas, it is important to say that Canada began the legalization of homosexual relationships in the turn of the millennium, in its provinces, until marriage was legalized for the whole country in 2005 - the first country to allow homosexual marriages outside Europe. Marriage was spread over the country in Brazil and Mexico, through court decisions.

\subsection{CURRENT LEVEL OF PROTECTION FOR SEXUAL DIVERSITY IN BRAZIL;}

In Brazil, some State jurisdictions started recognizing samesex partners the same status as heterosexual partners living in a civil union. The Court of Rio Grande do Sul first recognized it in $1999^{6}$. Then, other State Courts did the same and later also recognized the rights to succession and to joint adopt children for same-sex couples. However, the claims were usually risky, because a judge or a court could deny them, as our laws and codes said nothing about same-sex couples. The reference to marriage and civil unions as monogamical families composed by a man and a woman were referred to a specific

3 For a history of same-sex couples rights in Europe, see KESSLER, Guillaume. Les partenariats enregistrés en droit international privé. Paris, LGDJ, 2004.

4 See PIERCESON, Jason. PIATTI-CROCKER, Adriana. SCULENBERG, Shawn. Same-sex marriage in the Americas: policy innovation for same-sex relationships. New York, Lexington Books, 2010.

5 See BLAIR, Marianne. MALDONADO, Solangel. STARK, Barbara. WEINER, Merle H. Family Law in the World Community: Cases, Materials, and Problems in Comparative and International Family Law. 2 ed. Durham, Carolina Academic Press, 2009. p. 219-221.

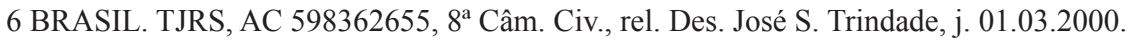


prohibition to same-sex couples.

In may 2011, the Supreme Federal Court - equivalent to a Constitutional Court - rendered a decision that recognized the same rights to homosexual couples living in a partnership as heterosexual couples living in a partnership have. The court did not list specific rights to be recognized, just indicated a general recognition, but it was a landmark for gay activists. The decision created a leading case, that should be followed by lower courts. From this decision on, no court in Brazil could ignore same-sex couples or limit their rights.

The 2011 Supreme Court decision ${ }^{7}$ did not talk about marriage, just about recognition as civil unions on the same basis as heterosexual couples. Nevertheless, as the Constitution and the Civil Code state that civil unions (partnerships) may be converted into marriage, some couples petitioned for it and some couples tried to get a direct permission to get married. Some couples did it directly to the notary, because they were asking an authorization to getting married. All couples do it for civil marriage, but it is never denied for straight couples. If a notary denies it, the parties may ask that a judge review it. A judge may review the decision or confirm it. It the parties are not satisfied with the judge's decision, they may appeal to the State Courts. A great variety of decisions were thus rendered in Brazil.

Some judges allowed the conversion, some not. Some also granted direct marriage, because they understood there could be no discrimination about marriage. The Higher Court of Justice - the Brazilian "Cour de Cassation" - rendered a decision recognizing the right of marriage for a lesbian couple, but it originated from an appeal on a case begun in the State of Rio Grande do $\mathrm{Sul}^{8}$. The decision was specific for this case but can be a reference for further cases. The Supreme Court has, nevertheless, never rendered a decision specific on gay marriage. She is expected to pronounce something favourable soon, because it is known that its Justices are pro same-sex marriage.

On the hope to end the battle of controversial decisions on samesex couples' rights, in may 2013, the National Council of Justice - an organ that controls all the Courts in Brazil - enacted a resolution that benefited same-sex couples ${ }^{9}$. Brazil has 27 jurisdictions for the States and D C. Family matters and successions are judged by these State jurisdictions, as well as notarial themes. Notaries in Brazil are always

7 BRASIL. Supremo Tribunal Federal. ADI 4277 e ADPF 133. Relator: Min. Ayres Britto. Tribunal Pleno, julgado em 05/05/2011, p. 656. Disponível em: <http://www.stf.jus.br/portal/ processo/verProcessoAndamento.asp?incidente=11872>. Acesso em: 22/05/2014.

8 STJ. REsp. 1183378/RS. Rel Min Luis Felipe Salomão. j. 25/10/2011.

9 OLIVEIRA, Mariana. Decisão do CNJ obriga cartórios a fazer casamento homossexual. Publicada em: 14/05/2013 Disponível em: <http://g1.globo.com/politica/noticia/2013/05/aposuniao-estavel-gay-podera-casar-em-cartorio-decide-cnj.html>. Acesso em: 30/05/2014. 
public and are submitted to the High Court of the State Jurisdiction where they work. The National Council of Justice prohibited all notaries to discriminate same-sex couples who petition for marriage. As notaries are submitted and are part of State jurisdictions and tribunals, it was possible to reach them. This way, marriage was allowed to gay couples in Brazil. Even if a notary denies it, the parties may appeal and be sure that they will get married.

A conservative party is challenging the legality of this resolution before the Supreme Court. We expect it to be judged soon. Maybe we finally get something concrete soon. The party allegates that it was illegal, the same old story that marriage should be exclusive for a man and a woman. They also say that the Council exceeded its power, because they were ruling a theme that should be ruled by specific voted by the Parliament. Until now, there is no specific law or rule in the Civil Code or in the Federal Constitutional about marriage for homosexual couples. There are projects on the Congress for it, as well as we have projects against gay rights.

\section{NEW HORIZONS FOR GAY RIGHTS IN BRAZIL?}

The most significant initiative to guarantee gay rights recently as done by the Brazilian Bar Association. In 2011 a Special Commission of Specialists was indicated to prepare a draft for a new act on human rights and sexual diversity. The goal was to promote citizenship and to fight the discrimination based on sexual orientation and gender identity. The idea was elaborating a new act where all sorts of rights for gays, lesbians, bisexuals, intersex and transsexuals were guaranteed.

The draft was approved by the Brazilian Bar Association in the end of 2011. Since then, the Association is collecting signatures, to present it to the Congress through liberal deputees, with the support of voters. The project is expected to arrive soon to the Congress.

The draft for an act on sexual diversity would be very positive for Brazil and for human rights in general. Brazil would be the first country to include in the same document all rules related to the protection of LGBTI citizens, in all aspects of their daily life: not only family matters, but also protection from discrimination in different situations, the criminalization of homophobia and the introduction of affirmative measures to try to change society into an inclusive environment for all people.

This way, the draft of this project for a new Statute of Sexual Diversity is included herein as an appendix to this work, to publicize this important initiative. 


\section{REFERENCES}

BLAIR, Marianne. MALDONADO, Solangel. STARK, Barbara. WEINER, Merle H. Family Law in the World Community: Cases, Materials, and Problems in Comparative and International Family Law. 2 ed. Durham, Carolina Academic Press, 2009.

FORNE, Byrne. Homophobia: a history. New York, Metropolitan Books, 2011.

KESSLER, Guillaume. Les partenariats enregistrés en droit international privé. Paris, LGDJ, 2004.

MARCUS, Eric. Making Gay History: the Half-Century Fight for Lesbian and Gay Equal Rights. New York, Harper Collins, 2002.

PIERCESON, Jason. PIATTI-CROCKER, Adriana. SCULENBERG, Shawn. Same-sex marriage in the Americas: policy innovation for samesex relationships. New York, Lexington Books, 2010. 


\section{FOREPROJECT OF THE BRAZILIAN SEXUAL DIVERSITY ACT10}

This Foreproject of the Brazilian Sexual Diversity Act is the result of the Work of the Special Sexual Diversity Commission of the Federal Brazilian Bar Association, which includes:

as its members:

President of the Commission - Maria Berenice Dias (Rio Grande do Sul)

Adriana Galvão Moura Abílio (São Paulo)

Paulo Marcos Freitas (Distrito Federal)

Marcos Vinícius Torres Pereira (Rio de Janeiro)

Paulo Tavares Mariante (São Paulo)

as its consultants:

Daniel Sarmento (Rio de Janeiro)

Luis Roberto Barroso (Rio de Janeiro)

Rodrigo da Cunha Pereira (Minas Gerais)

Tereza Rodrigues Vieira (São Paulo)

\section{EXPLANATORY MEMORANDUM}

The Brazilian Federal Constitution establishes the dignity, the freedom and the equality of every person as fundamental principles. Besides prohibiting discrimination of any kind, it guarantees the full exercise of citizenship rights by everyone. Nonetheless, infraconstitutional laws shall give effectiveness to constitutional guidelines, principles and norms.

Therefore, congressmen cannot flee from the duty of voting infraconstitutional laws, otherwise the constitutional mandate consisting of the inclusion in the legal system of all rights that shall be protected, would not be achieved.

The lack of a certain act does not correspond to the nonexistence

10 The version in English of this material is used by the Brazilian Bar Association for cooperation activities with other foreign juridical institutions. The Original version in Portuguese available at the official website of the Brazilian Bar Association(OAB):http://www. oab.org.br/arquivos/pdf/Geral/ESTATUTO_DA_DIVERSIDADE_SEXUAL.pdf Last access: January 24th 2012. 
of this hypothetical corresponding right, neither can leave someone out of the scope of State protection. Democracy corresponds to guaranteeing rights for every person, not only the rights of the majority. Moreover, the minorities that are affected by prejudice and discrimination deserve a different and more careful protection in order to have their rights recognized.

State nonfeasance is historical regarding the rights of homosexual, lesbian, bisexual, transsexual, transvestite, transgendered and intersex persons. The oppression not only turns such persons into invisible beings, but also turns them vulnerable to homophobic acts, and thus socially vulnerable.

Not only sexual orientation and gender identity are neglected by the Legislative Authorities, but same-sex unions are also not legally recognized. The Federal Constitution considers family as the basis of society. Although it protects family in a special manner, the Constitution refers expressly only to marriage, heterosexual civil unions and singleparent families. In the same way, it only recommends the conversion of the heterosexual civil union into marriage. This, however, does not mean that same-sex unions are not family entities and that such special protection is not given to these types of unions.

Not neglecting this reality, judges have been recognizing the rights of homosexual, lesbian, bisexual, transsexual, transvestite, transgendered and intersex persons for over a decade, both in federal and State courts. The number of decisions has overpassed the one thousand mark. Since 2001, same-sex unions have been recognized within the scope of Family Law and Succession Law, which includes social security rights, death benefits and the right of including a partner as dependant in health insurance. Moreover, dozens of decisions have ensured the property's marriage portion to partners, the right to become a tenant of joint-residence after the death of a partner, inheritance rights and also those rights regarding the property listing of the deceased. In the same way, adoption and application to adopt have been assured to same-sex couples. Even the Supreme Federal Court has already welcomed more than 40 cases regarding such issues.

There are so many court decisions, that some rights are now granted by the administrative instance. This is what happened with the death and confinement pension allowances granted by the National Social Security Institute, the indemnities arising from the Mandatory Insurance for Personal Damages Caused by Land Motor Vehicles, or by its Load, to Transported People or Not, and the issuing of permanent visas to foreign partners, granted by the Ministry of Justice. Moreover, the inclusion of a partner as dependent in income tax filings is also possible.

Recently, a Supreme Court decision (ADI No. 4.277 and ADPF 
No. 132, Rapporteur Minister Ayres Britto, judged on May $5^{\text {th }}$, 2011) unanimously recognized same-sex unions as family entities. Justices issued an accurate constitutional interpretation to Article 1,723 of the Civil Code, in order to exclude any interpretation that could prevent the recognition of a continuous, public and lasting same-sex union as a "family entity", which shall be understood as a perfect synonym to "family". Such recognition is supported by the same rules and has the same consequences of the heterosexual unions.

Such ruling became a historical milestone.

The Supreme Court did not trespass the National Congress functions - it did not legislate. It simply accomplished its duty, as set forth under the Constitution, of fulfilling legislative gaps. Justices also incited the legislators to comply with their duty.

As it was a definitive decision in a Direct Action of Unconstitutionality, it has binding effects over all courts and judges and over both direct and indirect public administration (Federal Constitution, Article 102, § 2). Thus, enforcement mechanisms regarding legal rights shall be created, homophobia shall be criminalized and public policies addressing the social inclusion of gay, lesbian, bisexual, transgender, transvestite, transgendered and intersex persons shall be adopted, under supervision of a legal system.

There is no doubt about the existence of a subjective right to the enjoyment of free sexual orientation and gender identity. As a result, there is a legal duty of recognizing and respecting such right. However, as it is a target segment of religious persecution, it is subject to marginalization and social exclusion. And, like every vulnerable social group, it deserves different protective rules.

The way modern States have found to ensure visibility and safety to those who are targeted by prejudice and discrimination is to establish legal microsystems that include the imposition of Affirmative Actions. Hence the Consumer's Protection Code, the Children's Act, the Elderly's Statute and the Racial Equality Statute. The issuing of a special act for LGBT groups is not a transgression of the Principle of Equality. On the other hand, such actions consecrate such principle, as well as different treatment guarantees equality.

Besides listing some principles, the Sexual Diversity Act establishes family and criminal rules which set various prerogatives and rights to homosexual, lesbian, bisexual, transsexual, transvestite, transgendered and intersex persons. Furthermore, it legally recognizes same-sex unions and criminalizes homophobia, and also points out public policies that aim at the inclusion of such persons in society.

Whereas several rights are related to LGBT rights as a consequence of their recognition, the approval of the Sexual Diversity Act is not enough. Infra-constitutional rules shall be rectified, excluded 
and amended. This way, this act also predicts the changes on many labour, private, social security, and criminal rules, in order to guarantee the recognition of citizenship to those who are still excluded from the brazilian legal system.

Many bills and constitutional amendments have been proposed and analyzed - some of them are still pending - in the National Congress. So far, no approval has been achieved yet. Therefore, many of such proposals have been incorporated into this Act.

It is time to end the legal invisibility of this segment of the population, which is targeted by vicious discrimination on the grounds of sexual orientation and gender identity.

Society shall change its paradigm. Every person shall learn to coexist with difference. Not only in the public sphere, but in the various segments of private enterprise. Nonfeasance, which contributes to social and moral harassment at school and at work, shall no longer exist. Likewise, we must end homophobia, criminalizing the discrimination, injure and kill.

Therefore, the Sexual Diversity Act shall be immediately approved, considering that it establishes a series of rights and privileges for those who are still not recognized as holders of rights: homosexual, lesbian, bisexual, transsexual, transvestite, transgendered and intersex persons. It is also important to insert homosexual ties within the field of Family Law, including its consequences and related rights.

Only the issuing of a set of rules shall impose not only the legal recognition, but also the social respect, to this part of the population, which is still targeted by prejudice and discrimination.

\section{GENERAL PROVISIONS}

Article One - This Sexual Diversity Act aims to promote the inclusion of all, to combat discrimination and intolerance on the grounds of sexual orientation or gender identity and criminalize homophobia, in order to ensure the promotion of equal opportunities and the protection of individual, collective and diffuse rights.

Article Two - It is recognized equal legal dignity to heterosexual, homosexual, lesbian, bisexual, transsexual, transvestite, transgendered and intersex persons as individuals and also in communion and social relationships, being respected the different ways through which they lead their lives according to their sexual orientation or gender identity.

Article Three - It is a duty both of the State and the Society to ensure the full exercise of citizenship, equal opportunities and the right to participate in community activities, especially in the political, economic, business, educational, cultural and sport activities. 


\section{FUNDAMENTAL PRINCIPLES}

Article Four - Constitute fundamental principles for the interpretation and application of this Act:

Human dignity;

Equality and respect to the differences;

Right to free sexual orientation and gender identity;

Recognition of the personality according to gender identity;

Right to have a family and to community life;

Freedom to establish bonds of family and parenting;

Respect to intimacy, privacy and self-determination;

Fundamental right to happiness.

$\S 1$ st - In addition to the constitutional rules which enshrine principles, guarantees and fundamental rights, this Act adopts as political and juridical guidelines the inclusion of victims of gender inequality and the respect to sexual diversity.

\$2 2nd - The principles, rights and guarantees specified herein do not exclude others stemming from the constitutional and legal rules in force in the country and from international treaties and conventions to which Brazil is a signatory.

§ 3rd - For the purposes of this Act, the Yogyakarta Principles, approved in Indonesia on November 9th, 2006 shall be also observed.

\section{RIGHT TO FREE SEXUAL ORIENTATION}

Article Five - Freedom of sexual orientation and gender identity shall be deemed as fundamental rights.

$\S 1$ st - State, family or society interference is undue when aiming to restrain someone from fulfilling his or her sexual and emotional relationships.

§ 2nd - Every person has the right to conduct his or her private life, not being admitted pressure to reveal, renounce or change sexual orientation or gender identity.

Article Six - No person shall suffer discrimination on the grounds of sexual orientation from any member of his or her family or community.

Article Seven - The freedom of conscience and belief is inviolable, being any practice that requires one to renounce or deny his or her sexual identity prohibited.

Article Eight - Hate speech or conducts that preach segregation on the grounds of sexual orientation or gender identity are forbidden.

\section{RIGHT TO EQUALITY AND NON-DISCRIMINATION}


Article Nine - No one shall be discriminated against nor have rights denied on the grounds of his or her sexual orientation or gender identity in public, social, family, economic or cultural fields.

Article Ten - Discrimination shall be considered any act that:

Establishes distinction, exclusion, restriction or preference which has the aim of nullifying or limiting the rights and privileges granted to other citizens;

Prevents the recognition or exercise, on an equal basis, of human rights and fundamental freedoms in the social or family sphere;

Represents a violent, an embarrassing, an intimidating or a vexatious behavior.

Article Eleven - It is considered discriminatory on the grounds of sexual orientation or gender identity:

Prohibit the entrance or the presence of someone in a public or private property opened to the public;

Provide selective or differential treatment not provided by law;

Pretermit, charge a higher price or prohibit someone to be lodged in hotels, motels, inns or similar establishments; or goods;

Hinder or prevent the rental, purchase, leasing or loan of property

Prohibit public display of affection in public spaces, while demonstrations of the same kind are allowed to other citizens.

Article Twelve - The practice of any such acts or other discriminatory practices configures crime of homophobia, according to this Act, in addition as civil liability for material and moral damages.

\section{RIGHT TO FAMILY LIVE}

Article 13 - All persons have the right to constitute a family and are free to choose the family model they suit in, regardless of their sexual orientation or gender identity.

Article 14 - Same-sex unions shall be respected in their dignity and shall be especially protected by the State as family entities.

Article 15 - The same rights applicable to heterosexual unions are applicable to same-sex unions regarding Family Law and Succession Law, among such rights:

Right to marry;

Right to constitute a civil union and to convert it into a marriage;

Right to choose a model of property system to regulate their marriage or union;

Right to divorce;

Right to exercise parenthood, to adopt children and to use assisted reproduction technologies;

Right to be protected against domestic or family violence; 
Inheritance rights, right to become a tenant of a joint-residence after the death of a partner and succession rights regarding partners.

Article 16 - All rights applicable to heterosexual unions are applicable to same-sex unions, such as those regarding social security, as well as fiscal and tax rights.

Article 17 - Foreign partners have the right to hold permanent visas in Brazil arising from the celebration of marriage or constitution of a civil union with Brazilian partners, as long as all legal requirements are fulfilled.

Article 18 - The law from the country where the same-sex family lives in determines the applicable Family Law rules.

Article 19 - Marriages, civil and stable unions celebrated or constituted in foreign countries shall be recognized in Brazil, as long as the formal proceedings required in the country of celebration or constitution have been observed.

\section{RIGHT TO PARENTHOOD, CUSTODY AND ADOPTION}

Article 20 - The right to exercise parenthood, individually or within a civil union, regarding biological, adopted or social-affective children is hereby recognized, regardless of sexual orientation or gender identity.

Article 21 - The access to assisted reproductive technology is ensured through private healthcare or state-provided healthcare through the assistance of the Unified Healthcare System, individually or jointly.

Sole Paragraph - The use of the couple's genetic material for reproductive techniques is allowed.

Article 22 - Parenting rights cannot be limited or vanished due to sexual orientation or gender identity.

Article 23 - The right to individual or joint adoption of children and adolescents cannot be denied, under equal conditions, due to sexual orientation or gender identity of the applicants.

Article 24 - The custody and the single or joint adoption of child and adolescents cannot be denied due to the sexual orientation or gender identity of those who are able to adopt.

Article 25 - The parental leave of one hundred and eighty days is assured to any of the parents, with no harm to the job position and wage.

$\S 1$ 1st - During fifteen days after the birth, adoption or custody concession for adoption, the birth leave is assured to both parents.

§ 2nd - The following remaining term of the parental leave may be enjoyed by any of the parents.

Article 26 - Upon the establishment of the social-affective bound, it is assured the right of parenting, even if the couple is divorced 
or separated.

Article 27 - Whether the separation or divorce occurs, shared custody shall be applied, regardless of the existence of biological bounds between the child and the parent.

Article 28 - The single custody shall only be deferred when proven to be the best way to protect the development of the child, being granted to the parent that has the best connection and affection level with the child.

Article 29 - The right of family companionship is guaranteed to parents and relatives.

Article 30 - The duty of financial support and education is a duty of both parents, even after the termination of the family companionship period.

Article 31 - Children cannot suffer family discrimination when revealing his or her sexual orientation or gender identity.

Sole Paragraph - The home expulsion of an underage person generates liability for material abandonment and the indemnity financial maintenance to the parents or legal guardians.

Article 32 - Birth certificates and all others identity documents, such as identity card, voter's register, passport, driver's license, shall not have any mention to the words 'father' or 'mother', having such words to be replaced by 'parents'.

\section{RIGHT TO GENDER IDENTITY}

Article 33 - Transsexual, transvestite, transgendered and intersexual persons have the right to freely express their gender identity.

Article 34 -The qualification of human resources of health professionals is indispensable in order to support transsexual, transvestite, transgendered and intersexual persons in their needs and specificities.

Article 35 - It is assured the access to medical, surgical and psychological procedures for the adaptation of the morphological sex to the gender identity.

Sole Paragraph - It is guaranteed the rendering of the procedures of hormonal therapy and sexual reassignment surgery in the private system or Unified Health System.

Article 36 - Having no risk to their own life, it is forbidden the rendering of any medical or surgical intervention of irreversible nature for the determination of the gender of newborns and children diagnosed as intersexual.

Article 37 - Having therapeutic indication from medical or multidisciplinary team for hormonal therapy and non-surgical complementary procedures, the adaptation to gender identity can begin 
from the age of 14 (fourteen).

Article 38 - Sexual reassignment surgeries can only be performed from the age of 18 (eighteen).

Article 39 - It is recognized the right to name and sexual identity rectification to transsexual, transvestite and intersexual persons so that they can adapt to their psychic and social identity, regardless of the realization of a sexual reassignment surgery.

Article 40 - Court orders determining name and gender change of transsexual, transvestite and intersexual persons shall be registered at the Civil Registry of Natural Persons Book.

Sole Paragraph - Certificates cannot contain any reference to the rectification, except if required by the party or due to a court order.

Article 41 - When one's name or gender is changed due to a court order, the rectification is assured in all others certificates and documents, without any mention to the reason of the modification

Article 42 - The military recruitment of transsexual, transvestite and intersexual persons shall be performed on a special date and in a private manner, by issuing of a simple requirement before the Military Service Center.

Article 43 - The Certificate of Military Recruitment shall be issued or cancelled upon the presentation of the rectification mandate delivered to the Civil Registry.

Article 44 - It is guaranteed to transsexual, transvestite and intersexual persons, which have a gender identity distinct of their morphological sex, the right to hold a social name, by which they are recognized and identified in their community:

In all government offices of direct and indirect administration, in federal, state and municipal spheres;

In registry forms, forms, prompt-books, among others documents of government service in general;

In academic certificates of elementary schools, high schools and universities.

Article 45 - In all public spaces and spaces opened to the public, one shall use the facilities and accommodations which correspond to his or her gender identity.

\section{HEALTH RIGHTS}

Article 46 - It is forbidden for health professionals to use means and techniques that create, maintain or reinforce prejudice, stigmas or discriminatory stereotypes regarding one's sexual orientation or gender identity.

Article 47 - Any discrimination on the grounds of sexual orientation or gender identity in hospitals, clinics, health centers and 
medical offices is prohibited.

Article 48 - The inclusion of the items 'sexual orientation' and 'gender identity' in forms and prompt-books of public and private hospital systems is mandatory.

Article 49 - The access to universal and egalitarian services of Unified Healthcare System is guaranteed, regardless of sexual orientation or gender identity.

Article 50 - The sexual orientation and/or gender identity cannot be used as criteria for the selection of blood donors.

Sole Paragraph - The collecting entities cannot ask the sexual orientation of those who voluntarily submit themselves as donors.

Article 51 - Hospital wards have to respect and preserve the gender identity of the patients.

Article 52 - Physicians, psychologists and other health professionals cannot exercise any action that consider homosexual behaviors or practices as pathologies, neither take enforcement actions tending to guide homosexuals, lesbian, bisexual, transsexual, transvestite, transgendered or intersexual persons to unrequested treatments.

Article 53 - It is forbidden to offer sexual orientation or gender identity reversal treatments, as well as making healing promises.

\section{SOCIAL SECURITY RIGHTS}

Article 54 - Equal social security rights are guaranteed to all people, regardless of their sexual orientation or gender identity.

Article 55 - It is forbidden for insurance or social security institutions, state-owned or private, to deny any kind of benefit based on the beneficiary's homosexual, lesbian, bisexual, transsexual, transvestite, transgendered or intersexual condition.

Article 56-Private healthcare companies cannot deny or restrict the inscription of the same-sex spouse or partner of the beneficiary as a dependent in health insurance plans.

Article 57 - The same-sex spouse or partner has the right to a death pension, a confinement allowance and to all others rights as a beneficiary before the National Social Security Institute.

Article 58 - The spouse or partner in a same-sex union has the right, as a preferential dependent, to receive a death indemnity as a beneficiary of the Mandatory Insurance for Personal Damages Caused by Land Motor Vehicles, or by its Load, to Transported People or not DPVAT insurance.

\section{RIGHT TO EDUCATION}

Article 59 - Schools must curb in the school environment 
situations that aim to intimidate, threaten, embarrass, offend, punish, submit, ridicule, defame, slander, or expose students to physical or moral embarrassment due to their sexual orientation or gender identity.

Article 60 - Education professionals have the duty to address the issues of gender and sexuality from the perspective of sexual diversity, aiming to overcome all forms of discrimination, making use of teaching materials and methodologies which propose the elimination of homophobia and prejudice.

Article 61 - Schools must adopt materials that do not reinforce discrimination based on sexual orientation or gender identity.

Article 62 - When scheduling activities related to school holidays or celebrations, schools must observe the various family models in order to avoid any embarrassment of students who have homosexual parents.

Article 63 - Teachers, principals, supervisors, psychologists, psychoeducators and all those working in schools have a duty to avoid any bigotry or discrimination against students from families with homosexual parents.

Article 64 - The government shall promote the training of teachers for inclusive education, as well as actions that aim increasing school enrollment of gay, lesbian, bisexual, transgender, transvestite, transsexual and intersex persons, in order to prevent school dropout.

Article 65 - In elementary, secondary and higher education, it is allowed to transsexuals, transvestites, transgender and intersex persons, upon registration, the use of their social name, which shall be used in all academic records.

\section{RIGHT TO WORK}

Article 66 - Access to the job market is guaranteed to all persons, regardless of sexual orientation or gender identity.

Article 67 - It is prohibited to inhibit the entry, the hiring or the promotion in the private or public service, on the grounds of sexual orientation or gender identity.

Article 68 - When selecting candidates, there cannot be any distinction or exclusion on the grounds of sexual orientation or gender identity.

Article 69 - It is a discriminatory practice to establish or maintain differences in wages between employees who work in the same functions as a result of their sexual orientation or gender identity.

Article 70 - It is a discriminatory practice to dismiss an employee based, directly or indirectly, on his or her sexual orientation or gender identity.

Article 71 - The government shall establish training programs for professional qualification, employment and income generation 
aimed at homosexuals, lesbians, bisexuals, transsexuals, transvestites, transsexuals and intersex, to ensure equal opportunities for them to have access to the job market.

Article 72 - It is guaranteed to transsexuals, transvestites, transgendered and intersex persons, the registration of their social names in the Labor and Social Security ID Card and all functional settlements, having those persons to be identified with such names in the workplace.

Article 73 - The government shall ensure equal opportunities for the employment of transvestites and transsexuals, transgender and intersex, observing the principle of proportionality.

Sole Paragraph - Mechanisms to encourage the adoption of similar measures in companies and private organizations shall be established.

Article 74 - The government and the private sector shall promote campaigns aimed at raising the qualification of transvestites, transsexuals, transgender and intersex.

Article 75 - Any restrictions to the acquisition or lease of property due to the sexual orientation or gender identity of the purchaser or lessee are prohibited.

Article 76 - Public or private financial agents must ensure access to home ownership to same-sex families.

Sole Paragraph - The combined income of a couple for the granting of housing financing is ensured.

Article 77 - The administration of the private property or condominium must inhibit any behavior that constitutes discriminatory practice under this act, otherwise liability on the grounds of civil damages may be applied.

Article 78 - Programs, projects and other governmental actions in the scope of the National System of Social Interest Housing must consider the social and economic characteristics resulting from sexual orientation and gender identity.

Article 79 - States, the Federal District and Municipalities shall stimulate and facilitate the participation of organizations and social movements in the composition of boards constituted for the purpose of application of the National Fund for Social Housing.

\section{RIGHT TO HAVE ACCESS TO THE JUDICIARY, SAFETY AND SECURITY RIGHTS}

Article 80 - Lawsuits in which sexual orientation or gender identity rights are disputed shall be deemed as classified information.

Article 81 - Lawsuits in which sexual orientation or gender identity are disputed shall be identified in order to statistics to be 
compiled.

Article 82 - Non-criminal lawsuits shall be judged by Family Courts and appeals shall be judged by Chambers Specialized in Family Law within the State Courts, if existent.

Article 83 - States, the Federal District and Municipalities shall establish support centers in order to provide support to homosexual, lesbian, bisexual, transsexual, transvestite and intersexual persons that suffer from situations of violence so that their physical, psychic, social and juridical integrity can be guaranteed.

Article 84 - Police stations specialized in receiving accusations regarding prejudice on the grounds of sex, sexual orientation or gender identity shall be established.

Article 85 - Conjugal visits in prisons shall be authorized, regardless of the prisoner's sexual orientation or gender identity.

Article 86 - The incarceration within the prison system shall consider the prisoner's sexual identity, having the prisoner to be jailed in a separate cell if there is risk to the prisoner's physical or psychic integrity.

Article 87 - Victims of discrimination shall be supported by the State in order to be sheltered, oriented, directed to the competent authority and for the investigation of criminal practices.

Article 88 - The State shall implement public policies in order to qualify civil and military policemen, as well as penitentiary officers, so that discrimination on the grounds of sexual orientation or gender identity is avoided.

Article 89 - The State shall adopt measures for the repression of police violence against homosexual, lesbian, bisexual, transsexual, transvestite, transgendered and intersexual persons.

Article 90 - The State shall implement resocialization and protective actions aimed at the youngsters in conflict with the law and socially excluded due to his or her sexual orientation or gender identity.

Article 91 - The administration shall create reference centers in Public Security Bureaus in order to provide shelter, orientation, support, direction to the competent authority and investigation of crimes motivated by discrimination on the grounds of sexual orientation or gender identity.

\section{MEANS OF COMMUNICATION}

Article 92 - Homosexual, lesbian, bisexual, transsexual, transvestite, transgendered and intersexual persons shall be respected in all means of communication, such as radio, television, advertising, the Internet and social networks, so that the physical and psychic integrity of such persons are protected. 
Article 93 - The means of communication shall restrain themselves from making any prejudiced reference regarding one's sexual orientation or gender identity.

Article 94 - It's a discriminatory practice to publish, exhibit or show any sign, symbol or badge that stimulate intolerance or violence.

\section{CONSUMER RELATIONS}

Article 95 - Every consumer has the right to be well treated, regardless of his or her sexual orientation or gender identity.

Article 96 - It shall be considered a discriminatory practice to deny the supply of goods or the rendering of services to a consumer due to his or her sexual orientation or gender identity.

Article 97 - No consumer shall be treated differently from other costumers for being homosexual, lesbian, bisexual, transsexual, transgendered or intersexual.

Article 98 - No public or opened to the public establishment shall retain someone from entering its facilities or establish restrictions on the grounds of sexual orientation or gender identity.

Article 99 - Public and private services shall qualify their staff so that they can serve costumers correctly, avoiding any prejudiced or discriminatory behavior on the grounds of sexual orientation or gender identity.

\section{CRIMES}

\section{Crime of homophobia}

Article 100 - To practice any discriminatory or prejudiced behavior as foreseen in this Act due to sexual orientation or gender identity:

Penalty - Reclusion from 2 (two) to 5 (five) years

Sole Paragraph - Any kind of behavior that stimulates hate or preaches that someone is inferior due to his/her sexual orientation or gender identity is liable on the same penalty.

\section{Incitation of violence}

Article 101 - To incite someone to practice a violence act in any way motivated by prejudice on the grounds of sex, sexual orientation or gender identity:

Penalty - Reclusion from 1 (one) to 3 (three) years, besides the penalty applied to the violence.

\section{Discrimination in the job market}

Article 102 - Not to hire someone, or make his or her hiring difficult, when the skills required for the job or function are fulfilled, motivated by prejudice regarding sex, sexual orientation or gender 
identity:

Penalty - Reclusion from 1 (one) to 3 (three) years.

$\$ 1$ st - The Penalty shall be raised in one third if the discrimination happens in the application for government jobs, functions and contracts.

§ 2nd - Whoever discriminates someone during the existence of the labor contract or job relation on the grounds of sex, sexual orientation or gender identity is liable on the same penalty.

\section{Discrimination within consumer relations}

Article 103 - To refuse or deny access to someone in a commercial establishment of any kind or deny treatment, motivated by prejudice on the grounds of sex, sexual orientation or gender identity:

Penalty - Reclusion from 1 (one) to 3 (three) years.

Article 104 - In any offense that a homophobic motivation is configured, the penalty shall be raised in one third.

\section{PUBLIC POLICIES}

Article 105 - The Union, the States, the Federal District and the Municipalities must adopt public policies that aim to create awareness of the society regarding the equal dignity of heterosexual, homosexual, lesbian, bisexual, transsexual, transvestite, transgendered and intersexual persons.

Article 106 - Participation under equal conditions of opportunity, in the economic, social, political and cultural lives of the Country shall be promoted mostly by the:

Inclusion in the public policies of economic and social development;

Modification of the institutional structures of the State for the proper combat and overcoming of inequalities arising from prejudice and discrimination on the grounds of sexual orientation or gender identity;

Promotion of normative adjustments in order to improve the fight against discrimination and inequalities within individual, institutional and structural manifestations;

Elimination of historical, social, cultural and institutional obstacles that deadlock the representation of sexual diversity in both public and private environments;

Stimulation, support and fortification of the initiatives arising from the civil society aimed to the promotion of equal opportunities and fighting of inequalities, also through the implementation of incentives and conditioning and priority criteria for the access to public resources;

Implementation of affirmative action programs in order to combat inequalities regarding education, culture, sports and leisure, health, security and safety, work, housing, means of mass communication, 
public financing, access to land ownership, access to the Judiciary, among other fields of life.

Article 107 - Upon the implementation of programs and actions in the Pluriannual Plans and in the Annual Budgets of the Union, the States, the Federal District and the Municipalities, public policies that aim to promote equal opportunities for and social inclusion of heterosexual, homosexual, lesbian, bisexual, transsexual, transvestite, transgendered and intersexual persons shall be observed, especially those related to the:

Promotion of the equal opportunities for the access to health care, education, employment and housing;

Stimulation for the creation of programs and means of communication aimed to combat prejudice, discrimination and homophobia;

Support of programs and projects of the Federal, State, District and Municipal governments and civil society entities aimed to the promotion of social inclusion and equal opportunities.

\section{FINAL AND TRANSITORY PROVISIONS}

Article 108 - The actions set by this Act do not exclude others in benefit of homosexual, lesbian, bisexual, transsexual, transvestite, transgendered and intersexual persons that have been or may come to be adopted in the Union, States, Federal District or Municipalities.

Article 109 - The Executive branch shall create instruments to verify the social effectiveness of the actions established in this Act and shall monitor it constantly, with the issuing and propagation of periodic reports, also available through the World Wide Web.

Article 110 - (List the legal provisions of Brazilian Law in an Annex, including all rules that shall be modified, amended or excluded)

Article 111 - This Act enters into force on the date of its publication. 